\title{
COSMIC ECOLOGY
}





\section{GEORGE A. SEIELSTAD}

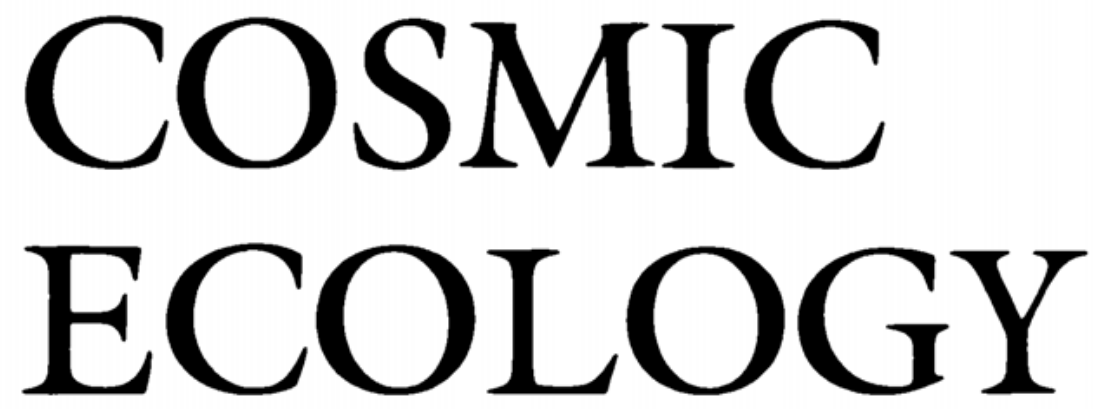

THE VIEW

FROM THE OUTSIDE IN

UNIVERSITY OF CALIFORNIA PRESS

Berkeley Los Angeles London 
University of California Press

Berkeley and Los Angeles, California

University of California Press, Ltd.

London, England

Copyright (C) 1983 by The Regent of the University of California

Library of Congress Cataloging in Publication Data

Seielstad, George A.

Cosmic ecology.

Includes index.

1. Cosmology. 2. Evolution. I. Title.

$\begin{array}{llll}\text { QB981.S445 } & 1983 & 523.1 & 82-15944\end{array}$

ISBN 0-520-04753-2

Printed in the United States of America

$\begin{array}{lllllllll}1 & 2 & 3 & 4 & 5 & 6 & 7 & 8 & 9\end{array}$ 
To posterity, in the hope that there may be one; and especially to those immediate links which Dolores and I have forged with the forever after. . . Andrea, Carl, and Mark. 
